Psychology. Journal of the Higher School of Economics.

2019. Vol. 16. N 1. P. 50-66. DOI: 10.17323/1813-8918-2019-1-50-66

\title{
TYPES OF THINKING AND THEIR VALUE FOR ECOLOGICAL EDUCATION
}

\section{L.V. SMOLOVA ${ }^{\mathrm{a}}$}

${ }^{a}$ St. Petersburg State Institute of Psychology and Social Work, 13A 12th Line, Vasilyevsky Island, St. Petersburg, 199178, Russian Federation

\begin{abstract}
In this article types of thinking - mythological, totemic, formal, logical, associative, figurative, and abstract - are theoretically analysed regarding their possible contributions to ecological attitudes. The value and uniqueness of each type of thinking as a way of knowing the world is emphasized. The continuity, complication, and evolutionary character of the types of thinking (that are in a certain hierarchical relationship) are described. The potential for all types of thinking to be presented in each person is specified. It is noted that each phenomenon (a situation, an event, or a subject) can be considered from the angle of different types of thinking: it will only enrich the perspective and complement the knowledge of it. The possible contribution of each type of thinking to ecological education is described. It is emphasized that the types of thinking are conscious or unconscious tools, the application of which is possible and necessary in order to clarify reference points and triggers that form the basis of ecological behavior, as well as to help to a person of any age to learn to think integrally and systematically. Understanding the types of thinking will assist people in their search for their personal sense of sympathetic behavior to the environment.
\end{abstract}

Keywords: types of thinking, system thinking, ecological thinking, ecological attitudes, ecological education, sustainable development, the Club of Rome.

\section{Introduction}

In November, 2017 there was an event of (without exaggeration), universal scale: The Club of Rome published a report in time for the semicentennial anniversary on the subject of "Come on! Capitalism, short-sightedness, population and destruction of the planet" (von Weizsaecker \& Wijkman, 2018).

The idea of 'The New Enlightenment' became a key point of the report: the need to reject materialism and reductionism, to make a transition to a holistic outlook, and a fundamental transformation of thinking resulting in a radical paradigm shift of our civilization's development.

Regarding the purpose of education in general, the Club envisions populations developing "literacy concerning the future", namely, a focus on sustainable development, the coherence of systems, and the cultivation of thinking that is integrated and beyond the analytical. 
Ecological thinking as a combination of ecological understanding and environmental awareness (Balgopal \& Wallace, 2009). Ecological thinking involves understanding concepts in ecology, including biotic factors, abiotic factors, and biotic interaction. It is complemented by understanding the impact of human activity on ecosystems (Norizan, Hashimah, Nooraida, Mahamad, \& Mardiana, 2018; Woolpert, 2004).

Mitchel Resnick suggests a very unusual metaphor: to think ecologically is to think like a tree, specifically a walking tree. He explains that the walking tree follows a "tree strategy: 1) Test Randomly (send out roots in all directions); 2) Evaluate (determine which roots find the best soil); 3) Elect (choose which direction to move, based on the information from the roots)" (Resnick, 2003). In other words, ecological thinking is connected to the ability to think on a substantial scale, consciously, and attentively.

That makes this category close to system thinking (Gharajedaghi, 2011; O'Connor \& McDermott, 2012; Smolova, 2019). System thinking is a framework based on the belief that component parts of a system can be understood best in the context of the relationship with each other and between systems, rather than in isolation. The only way to fully understand why a problem or an element occurs and persists is to understand the part in relation to the whole (Capra, 1996).

Ecological thinking can be improved by ecological education, one of the goals of which is the education of a thinking person who has their own opinion and is capable of independently comprehending various phenomena, as well as making decisions, consciously and responsibly.

Ecological education is a continuous process of training, self-education, accumulation of experience, and personality development with the aim of forming valuable targets and standards of behavior, and obtaining specialist knowledge for the protection and management of the surrounding environment. It is realized in ecologically competent actions (Blenkinsop, Piersol, \& Sitka-Sage, 2018; Campigotto \& Barrett, 2017; Gifford \& Sussman, 2012; Hintz \& Lackey, 2017; Stevenson, Brody, Dillon, \& Wals, 2014). It is obvious that the ecological component cannot be considered separately from economic, social, political, religious, migration, and other processes and systems.

The purpose of this article is to describe the types of thinking and to show how they contribute to the increase in ecological thinking.

\section{Types of Thinking}

In psychology thinking is understood as a mental process of reflecting reality, the highest level of human knowledge and a person's creative activity (Meshcheryakov \& Zinchenko, 2003). Undoubtedly, thinking has close ties with, and directly depends on, such mental functions as perception, memory, imagination, and speech. It cannot be considered separately from the diversity of a person. Factors such as culture, religion, and the social rules of conduct in a given community exert an impact on thought; also internal experience, behavior stereotypes, outlook, and beliefs, etc. do. Looking at the development of the person in 
anthropogenesis, it can be said that thinking was formed together with the formation of mankind, constantly changing and improving it.

The works of many Soviet, Russian (Leontiev, 2008; Pogodin, 2013), and foreign researchers are devoted to the subject of thought (Baum, 2013; Pinker, 2008; Zook \& Allen, 2016).

The result of thinking - ideally - is the birth of a person's own thought. However, it does not always occur: not unfrequently the product of mental activity represents a conscious or unconscious retelling of other people's thoughts, or a formalistic study of some phenomenon. In each case, the principle of the birth of a thought will be a different.

To study the types of thinking, we have analysed scientific literature on philosophy, anthropology, psychology and the system approach. The basis of the analysis was formed by the following research methods.

Dialectical materialism adapts the Hegelian dialectic for traditional materialism that examines subjects of the world in relation to each other within a dynamic, evolutionary environment. Dialectical materialism accepts the evolution of the natural world and the emergence of new qualities of being at new stages of evolution.

System approach - the world is a set of elements interacting among themselves and forming a certain integrity, and mentality is an integrity comprised of elements that are closely connected among themselves and can't exist separately, out of this communication.

Determinism approach - a philosophical theory of all events, including moral choices, being determined completely by previously existing causes and processes happening in the world.

So, on the basis of a synthesis of anthropology, philosophy, system theory, and psychology, it is possible to delineate several types of thinking representing specific ways of knowing.

\section{Mythological thinking}

A myth (from Ancient Greek: speech, word; story, legend) is a narration passing on people's ideas about the world, a person's place within it, and about the origin of all that exists, gods, and heroes. The prevalence of mythological consciousness belongs mainly to an archaic (primitive) era (Campbell, 1972; Lévi-Strauss, 1999).

Characteristics of mythological thinking are (Lapitov, 2009):

- no separation of people from their surrounding nature, attribution of human characteristics and properties to natural objects;

- lack of a division between natural and supernatural;

- symbolic thinking;

- a belief in magic;

- no division between the subject and the object, material and ideal, spatial and temporary, etc.;

- a poor development of abstract concepts and strong elementary/sensory understanding. 
In discussing mythological thinking as one of the types of thinking of the modern person, we will remove the words "archaic" and "primitive": myth is not something that was left behind centuries ago and is no longer present in modern people. Each person uses their own myth as the beginning of their outlook and the basis for their picture of the world.

Mythological thinking initially is characteristic in children. More than likely this is the first thing a child meets: they have myths of the family, nature, and the surrounding world. In the creation of this myth a large role is played by fairy tales, stories told by adults that pass on their views of the world. Children love fairy tales and believe that Father Christmas and other magical beings exist not in their imaginations, but in real life. "The real reality" and the "fantastic unreal reality" are bound in a single whole.

Even serious and highly intellectual people have myths; beliefs in science, power, mathematics, figures, statistics etc. can be myths too.

However, here it is worth emphasizing an essential distinction: if a person does not understand something, for them it is a myth; if they have the ability to deeply comprehend a certain phenomenon, they use a higher type of thinking. For example, for some people nanotechnologies are a myth in which it is pleasant to believe. However, for scientists professionally engaged in this field nanotechnologies are real knowledge.

The strength of a myth is that its irrationality always gives an impetus for development. In life, it is not possible to explain everything using the mind, and a myth is the recognition that something is not understood.

The weakness of a myth (for an adult) is that a person quite often holds onto a myth without wishing to move further to independent deep judgment, the verification of this myth, and the formation of their own position. A myth prevailing over an adult brings them to the level of a child incapable of directing their life and of thinking independently.

Thus, mythological thinking is a process of handling information and establishing connections between objects or phenomena of the surrounding world. The connectedness of a person with their natural and social environment, and lack of differences between reality and visibility, is characteristic.

The ecological context. When speaking about children, it is very important for them to have created their own myth about the environment - not a frightening one, but one that provokes interest, responsibility, and personal relationships with the planet, nature, the realm of animals, plants, and minerals. While these relations are still fantastic and not formalized, they will be the cornerstone of the transformation of the myth into something more concrete and conscious.

Each adult also has a rather large number of ecological myths: about the ecological condition of a region, country, or the planet. People give birth to them as a result of selective perception, and also on the basis of stories offered by mass media, which often operates with rumors, gossip, and unverified or inexact messages.

Awareness of one's own myths about the ecological situation of a country or the planet, as well as the reasons for their appearance, becomes the first step for work on thought in ecological education. 


\section{Totemic Thinking}

The term "totem" was used for the first time by the English traveler J. Long in 1791, having borrowed it from the North American Ojibwa tribe, in whose language totem means "name" or "sign", the clan's symbol, and also the name of the animal that is the subject of the tribe's special cult.

Initially, totemic thinking (with the totem meaning "the protector") was based on the idea of a person belonging to a certain tribe (Frazer, 2015). The history of a person's origin, based on mythological thinking - a belief in the existence of the primogenitor, his wisdom, force, power, and final authority - was of great importance. In the history of mankind there was a gradual transition from the context of the primogenitor to that of the Protector.

For children totems are undoubtedly parents and significant people. Their decision is usually not criticized, and if exposed to criticism in certain cases, it is carried out all the same.

For adults totemic thinking is connected with the presence of an authority in their life. This authority can be a personal acquaintance or not, but most importantly a significant person. Their life story, qualities, and characteristics are, for any of several reasons, separated from a great number of others. A person builds their own life by taking this example into account: what will my mother think of me? What would my boss say about this?

Totemic thinking is the substitution of one's own thoughts and behavior with the thoughts, views and decisions of a totem, where the person steadily corresponds to the opinion of a "senior" and tries to imitate him or her.

At certain stages (especially during childhood) totems genuinely develop a person. The person builds themselves (and their general way of life) according to the chosen values. While these values are not yet appropriated, realized, or comprehended, the process to which a person wants to correspond is already started.

However, at a mature age, the comparison of one's own life with the life of even the most worthy person can slow down personal development, and even lead to a dead end. The presence of totems in adults limits their opportunities, as well as making them rigid, and not viable enough.

The ecological context. Returning to the ecological subject, it is necessary to emphasize the importance of understanding totems that a person is guided by when making decisions, and installations regulating their behavior.

Why turn off the light when leaving the room? Why not walk on lawns? Why is it necessary to dispose of batteries in special processing points? Why make nesting boxes and plant trees in spring?

For children the priority is the behavior of parents: "I do so because mother always does". For adults the imitation of an idol (a political leader, singer, relative, etc.) can be a cornerstone of ecological behavior.

Once again, we will emphasize that even in case of a friendly relationship with the environment the problem consists of repeating actions without sufficient judgment from oneself. 


\section{Formal Thinking}

Formal thinking is a sequence of intellectual actions by rules and templates fixed in advance.

The name contains the idea that thinking occurs in a form or forms. (The form (from Latin "appearance") is understood as a relative positioning of borders (contours) of a subject or object, and also as a relative positioning of points of the line.)

Formal thinking is focused directly on the form of actions carried out, without paying attention to their substantial context, logical analysis, and judgment. Interrelations between objects are described without emphasis on their validity or falsehood (for example: "Life is a difficult thing", "Who finds it easy now?").

Historically, formal thinking is connected with the development of social groups with clearly developed traditions. Independent thinking was not required from members of the societies' majority groups; it was not even absolutely essential for them to think, feel, or respond to any event. The most essential priority was the observance of the social order.

Having acquired the adopted rules, a person becomes successful in communication and a worthy member of society. There were often enough of these rules to have a social life, and to lead a socially approved life.

The strength of formal thinking is that a person does not need to spend resources (strength or time) on a detailed exploration of a certain action.

The weakness is that it is thought on a template or scheme set by somebody else. The person does not penetrate into the content of processes, but remains on the surface. As we see, in the first three types of thinking the process of knowing happens due to following the socially set rules and norms. Own thought, in this case, has not been born yet; it is rudimentary.

The ecological context. Quite often, people follow rules and norms only because the majority does so in this community. It can be inhabitants of closed communities, small towns and villages whose ecological behavior occurs on a habit: "we do as our fathers and grandfathers did". Sometimes they have no modern ecological technologies; sometimes, if they do, they don't want or don't know how to use them. However, the residents of big cities may also not want to analyze behavior in general and ecological behavior in particular.

This is due to an unwillingness to be separate from a group, as they have the opportunity "to be the same as everyone", without thinking of reasons for the behavior. Thoughtless repetition of what is done by other members of society is characteristic of formal thinking, and is shown on all levels including ecological. Thus, for example, in some communities, disposing rubbish directly onto the street is the norm; people don't think of what will happen afterwards.

Undoubtedly, if this behaviour is ecologically preserving, such a formalistic approach can be satisfactory. It is great when there are worthy examples to imitate, not just in the form of totems, but as standard norms. However, there is no guarantee that, if moved to another community, a person will behave in an environmentally friendly way there too. The key is his/her lack of freedom, and dependence on opinions of other people around. 


\section{Logical Thinking}

Historically, Western cultures give priority to logical thinking, which has had the longest history of development. Aristotle analysed the main forms of a thought (concepts, judgments) and also methods of cognitive activity. From the 17th century logical thinking becomes dominant in European sciences and philosophy. This is connected to the empirical stage of development of the European natural sciences, representing the Galilean-Newtonian picture of the world.

Logical thinking is the type of thinking that essentially operates using concepts, judgments, and conclusions according to the laws of logic. It is the thought process whereby a person uses logical concepts and designs, inherent to which are substantiality and judiciousness, and the purpose of which is to arrive at a valid conclusion from the available prerequisites.

Logical thinking is expressed in rationality and analyticity, that is, with the affirmation of the importance of mental activity. At some level, logical thinking is accompanied by rational thinking and the assumption that the cognitive process dominates while the sensual sphere is secondary.

The essence of analytical thinking is the application of logic in decision-making and analysis of information based on a person's ability to split the general whole into its components.

For an analytical task to be solved, the information is first split into separate components that are then comprehensively analyzed; several possible decisions are outlined; the strengths and weaknesses of each option are considered; and as a result the most optimal is chosen. It is noteworthy that missing information can be deduced by means of logical conclusions.

We will mark out some characteristic features of logical thinking:

- Substantiality (the need for justification, rejection of unfoundedness, and declarativity).

- Certainty (accuracy and unambiguity of thought, as well as lack of confusion in concepts).

- Sequentiality (structural communications and relations are consistently presented in time).

- Dichotomy (from Greek, meaning "division in two") (the division of a class into logical subclasses, given that the concept to be divided breaks into two mutually exclusive concepts (day/night; man/woman, etc.)).

- Consistency (the impossibility of the phenomena having contradictory values; the ban on any contradictions in life and, therefore, in cognition).

- Estimation (well/badly, correctly/incorrectly, etc., an investigation of the laws of non-contradiction as two opposing judgments cannot be true at the same time in the same context, with exclusion of a third judgement (from two contradicting judgments, one is true, another is false, and the third isn't given)).

- An opportunity to reveal relationships of cause and effect (the cause is always before the effect, preceding it). 
- Priority of mental functions (the sensual sphere, while the most dynamic, is given a secondary value in the informative process in general as well as in the course of the birth of own thought).

- A distinct prevalence of analytical procedures of research in comparison with synthesis methods.

So, using logical thinking, a person tries to receive the maximum quantity of valid and evidence-based conclusions. It is notable that, when perceiving an object, the person takes a certain position and does not change it throughout the whole process.

The purpose of logical thinking is the birth of own thought, which is the ability to synthesize information and knowledge and express it externally. Undoubtedly, the high-level ability of creating thought (as a unique unrepeatable event) is not one possessed by many people. People usually recount thoughts of others.

The ecological context. Thus, the person judiciously and rationally approaches any phenomenon, including those connected to nature. They are capable of creating own thought, explaining a given decision, evaluating their's or another's act, and revealing relationships of cause and effect.

Why is throwing rubbish directly onto the ground not permitted? Why is it necessary to collect waste paper? The answer often assumes the distinct logical answer of: "because the cultural person doesn't behave in that way", or, "because unnecessary paper can be recycled to print books". As we see, it is not a totemic, but a much higher outlook. The person explains their choice of behavior: "I behave so because ...", adding arguments of why they act in this way and not differently.

Many consider that the logical type of thinking is the most effective and high. But it is impossible to deny that similar bonds existing generally at the rational level work locally and are tied to a concrete existential continuum. They do not always involve communications at another level. In this type of thinking, there is not enough of an integrated vision of the connectedness of ecological processes in other systems. There is an understanding of the behavior, but there is not enough intelligence and awareness at a deeper level. Logical thinking has one main restriction: it is incapable of comprehending the life of systems.

\section{Associative Thinking}

Association (from Latin "connection", “interrelation”) is a communication between elements, objects or phenomena. The basis for association is a short-term conditional generation of mental communications that are responsible for the subject's similarity and analogy.

The use of associations and metaphors in daily life is natural and organic; very often people do it unconsciously. However, to have associations and to think using associations are different realities. For some people associations can appear from time to time, while others use them as their main way of knowing the world.

Associative thinking is a way of understanding the world and connections within it, through the use of associations as communications between separate representations and images when one of them involves the emergence of another. Associative thinking includes logical analysis, but arrives at a higher level. 
Associative thinking emphasizes the restriction of a dichotomizing approach, and the recognition of the meaning of the simultaneous existence of phenomena with contradictory values. It also recognizes the priceless and equal contribution of sensory and rational perception. The priority is given to synthesis as the connection of various elements of an object to a whole system.

The phenomenon of interest is woven into a web of communications that are organised not simply in a certain sequence between the "key" elements (as they are in chains of logical thinking) but between all the elements of a system. Associative thinking assumes a synthesis of associations as the discovery of complete contents of a phenomenon, irreducible to separate communications between parts and elements comprising it.

The result of associative thinking is the concept of a phenomenon as a nonlinear hierarchical synthesis of communications between elements of a system. The concept of the phenomenon defines its role in a given whole, introduces the relationships between the part and the whole, and makes the phenomenon necessary as a part of this whole.

The concept discovered using associative thinking helps a person to answer such questions as: "Why has this happened in my life? What is the point of this situation?" This is an engagement of intelligence and thinking on a new, deeper, level of development.

Associative thinking represents an entrance to systemic thinking, from which even more complicated types will follow: figurative and abstract.

The ecological context. Why do we have bicycle riding? Why do we have to bring our own mugs to the workplace rather than to use disposable cups? What is the purpose of separating rubbish?

When revealing the meanings of any phenomenon including those connected to the environment, the person goes beyond exclusively ecological themes. They are capable of seeing connections between various systems, social, economic, political, and others.

It is obvious that everything a person interacts with is a system. Systems possess the characteristics of openness, nonlinearity, instability, multidimensionality, and diversity, and do not follow the laws of formal logic.

Revealing a meaning, the person acts in some particular way not because it is good or bad, but because he/she finds an important reason for such an action. This helps build up a personal relationship with a given (including ecological or natural) phenomenon, and makes a person's behavior even more specialized.

\section{Figurative thinking}

Undoubtedly, images are used in all of the previous types of thinking. However, while most people have images, only some are able to think using images.

"Image" is used to describe the mental image formed in a person's consciousness of an object that is perceived by them and exists in the environment. Research on images in psychology is connected to perception, the result of which is the creation 
of a complete perceptual image of an object, but not its separate properties, and this information gives the person a sensation.

Perception always aims to create a complete perceptual image. However, the extent to which this is achieved depends on the person's abilities to synthesize feelings of various modalities. Information arrives from many sensory organs at the same time, creating sound, olfactory, flavoring, visual, kinesthetic, artistic, and other images. The person's task is to synthesize a uniform and whole image, without ignoring anything.

Figurative thinking is thinking in the form of images; through their creation, formation, transfer, operation, and modification by means of thought processes. It does not impart knowledge about the separate and isolated aspects (properties) of reality, but forms a complete mental picture of a separate part of reality. We will emphasize that the discussion is not just about the creation of associations between phenomena, and the ability to see quantitative and high-quality connections between them, but about their association in whole images and thinking with them. This type of thinking was the leading form in A. Einstein, N. Tesla, W.A. Mozart, etc. (Dilts, 2001).

It is remarkable that the greater the associations that arise to reveal different sides of an object, the deeper the image will be. However, associative thinking stops at revealing the features of connections, and identifying the meaning and value of these connections. Figurative thinking, on the other hand, is directed towards opening and deciphering that which stands behind these connections, having synthesized them as a whole, created an image, and entered its essence: what is it?

The essence is a quintessence, and the most precise answer to the question of who is who and what is what. The task of figurative thinking is the recognition of a complete image as being composed of systems, on the basis of identifying their essence.

Thus, figurative thinking is a process of cognitive activity directed towards the reflection of images' essential properties (their parts, processes, and phenomena) and the creation of whole entities of their structural interrelation.

Figurative thinking represents a hierarchically higher type of thinking containing within it a totally different principle of knowing the world. To understand the phenomenon (an event or subject), a person resorts to formal thinking; to analyze $i t$, to logical; to comprehend it, to associative; but if they want to realize it, they must think of it in the form of an indivisible image.

The ecological context. To look at an environmental problem in the context of figurative thinking means not to simply see connections linking it to other phenomena and systems, but to see the essence of what is happening.

What, in reality, occurs when a person participates in the activities of public organizations, such as looking after animals in shelters? What need do they satisfy? What value acts as the cornerstone?

When a person thinks about the essence of a phenomenon, they see beyond the surface of some, including ecological, phenomena. For this purpose, there must be sufficient information in the person's database; however, this is not enough by itself. The person synthesizes form and content, and compares it with other observations. The ability to distinguish and separate what is major from what is secondary. 
The ecological context passes into the background, and to the first there are moral and ethical values.

Why do I do it? It's good. That is how I express love. My conscience tells me to act like that. It's honesty.

Such a person cares for the environment, participates in ecological actions not because they have to or have some obligations. Not because others also do it, or it can be explained logically or even it makes sense. He just cannot act differently.

The person with figurative thinking is distinguished by the scale and depth of perception.

\section{Abstract Thinking}

In classical psychological literature abstract and logical thinking is often combined. Undoubtedly, they can be connected in the course of the performance of a task. However, abstract thinking, from our point of view, can and must be marked out as separate as it represents a qualitatively different and much higher means of knowing.

Abstraction comes from Latin «derivation»; it is the form of knowledge based on a mental separation of essential properties and connections of a subject from its other, particular properties and communications.

In dialectical logic, the abstract (a person in general, a handle, wood, etc.) is opposite to the concrete (my computer, this food, our house, etc.).

An abstract understanding is a mental design (presented in the form of numbers, notes, symbols, signs, images, metaphors, or objects that don't have a concrete form) capable of representing certain objects or phenomena of the real world, but at the same time separate from their concrete embodiments.

Thinking using abstractions begins during childhood, when a child says that clouds are similar to sheep or when they learn to manipulate a mobile phone or a computer. It develops in the course of education, especially when studying disciplines such as mathematics, physics, chemistry, biology, etc., where it is necessary to actively switch between abstract and concrete thinking.

It is shown particularly strongly in those professionals whose specialty is connected with thinking using abstract symbolical categories. In practicing psychologists this ability can be developed at a high level; a discussion of the client's concrete concern quite often demands recourse to a different level of discussion using abstract concepts (love, good, honor, etc.), with a subsequent return to the level of concrete practical actions.

To solve a concrete task, a person applying abstract thinking leaves «concrete reality»; addresses abstract concepts (symbols, images, notes, numbers, metaphors, etc.); solves a problem at the level of abstraction; then comes back to the concrete level, and applies it in what is called «matter».

However, it is clear that people carry out abstract tasks totally differently. This occurs most often at the level of execution: a person receives a task of executing a certain manipulation of symbols (to solve a mathematical, physical, or other problem). If they possess the minimum logical data, they will be able to perform it. 
A totally different situation occurs in the case where a person independently gives rise to an idea and embodies it at the concrete material level. The idea is an abstraction, a plan, or a mental prototype marking out the essential qualities of any action, subject, or phenomenon. The idea includes a conscious awareness of the aim and the practical transformation of the world.

However, for this purpose, a person has to think of a way, an action, and a will to embody the idea (as an abstract concept) on the concrete level - the level of physical matter. In this case the person becomes a pioneer and comparable to the Creator: they themselves create reality.

The complexity and scale of ideas will undoubtedly differ, someone realizes the idea of designing of a suit, another composes music, another devises medicine against cancer, and another invents new energy saving technologies.

In this way, thinking using abstractions consists of the conversion of attentional focus from the concrete to the abstract and vice versa for the purpose of performing a certain task. Abstract thinking is a way of knowing the world, the essence of which is the independent generation of an idea as an abstract mental prototype of an action (the symbolic level), and its realization at the level of a specific objective, for the purpose of a high-quality transformation of physical matter.

As we can see, it is also a systemic type of thinking, but on a much higher hierarchical level: in it, there is the ability to think on two levels of reality at the same time,- the abstract and the concrete, holding an image of both of them and their synthesis in general at the same time.

The ecological context. How to restore the ecosystem of a poisoned river? How to reduce harmful emissions in the atmosphere? How to create the device for waste-free technologies?

The person creating new ecological ideas and realizing them can become an example of abstract thinking in this context.

This is the professional who deeply knows the sphere of activity. This is the experimenter: he/she sets tasks and finds solutions of realization of the ideas of an ecological subject. He/she is capable to think of many systems at the same time: social, economic, ecosystems, and others, holding an image of all of them and their synthesis in general.

Such people, as we said, without exaggeration, are creators. Their creativity, freedom, ease of thinking, and perception scale usually inspires others. Such people become role models and it brings them to a deeper level of responsibility. They become responsible not only for realization of their professional ideas, but also for their actions, their style of life, and ecological behavior in everyday life.

\section{Discussion}

Having considered the types of thinking, we will sum up some results:

1. Each type of thinking is valuable in its own way and represents a unique way of knowing the world. Mythological thinking is consciously or unconsciously connected with the myth of life; totemic thinking is associated with reference points that the person has at various stages of their life; formal thinking is related to a focus on 
the external aspect of a given phenomenon. In logical thinking there is a birth of own thought; in associative thinking there is a creation of meaning; in figurative thinking there is an entry into the whole of a phenomenon and the identification of an essence; in abstract thinking there is an emergence of ideas and their realization in matter.

2. We will emphasize that there is a difference between having a given type of thinking and living by it. All people think, but not everyone can create their own thoughts. Associations are born in all people, but not everyone can see a meaning as a synthesis of connections from them. People are full of images, however, they are rarely capable of putting together the whole of a phenomenon and revealing its essence. Many are able of abstraction and moving from the particular to the general and vice versa, but very few have the talent to give rise to an idea and to embody it in matter and in life.

3. Each person potentially has all types of thinking. However, some are leading at a given moment in time, and these define a person's possibilities.

4. The types of thinking have certain hierarchical relations between them. Development of the subsequent form requires the formation of the previous. So, for example, to reveal essences, it is necessary to learn to show meanings and to give rise to thoughts. If it is difficult for a person to create a thought of their own as a synthesis of knowledge and information, they will not fully manage to capture the connections of the phenomenon of interest and will find it extremely difficult to comprehend meanings, let alone essences.

5. Continuity, complication, and the evolutionary character of types of thinking. When a person begins to be engaged in a new area, their thinking develops through all stages from mythological to abstract gradually becoming complicated and improved.

So, for example, a child encountering the subject of nature for the first time will perceive the ongoing processes locally. It will be difficult for them to combine the processes into an integrated picture. They will perceive a complete picture only as a myth; a fairy tale, in the creation of which adults will participate. Subsequently, it is possible to assume that the child will copy the behavior and views of significant persons, not fully understanding why they make one action or another ("mother collects waste paper, so I do too"; "grandfather plants trees in the spring, so I do too").

After a while there is a reorientation to the community, when a child or a teenager wants to be like everybody else and carry out the norms and rules adopted by him/her ("my school gives batteries for recycling, so I do too"; "at work putting garbage in separate baskets is expected"). The person does all this, but does so formally and to be a part of the community.

In a case where knowledge has sufficiently accumulated, the person has the ability to build relationships of cause and effect as well as draw conclusions. They can then synthesize information obtained from their own experience of outside world and express it as their own thought. Actions stop being formal, the person has their own opinion more often, and they make decisions independently and responsibly about any, including ecological, situations.

With the expansion of a person's outlook and also the emergence of one's own professional practice, there can be associative thinking when a mass of associations 
arises from a given phenomenon (including one connected with nature). Then, it is easier for a person to answer questions about the causes of a given phenomenon or the meanings of their own actions.

When a professional (in any area) works confidently in theoretical and practical fields, they can have figurative thinking, an insight into the essence of a studied phenomenon that is not learned but instead comes from the depths of personal experience. The ecological context will be deeply interwoven into connections of various quality, level, and order.

The improvement of a professional skill is connected with the development of abstract thinking, spontaneous emergence of ideas, and an easy and natural transition from the abstract to the concrete and vice versa.

6. Heterogeneity of types of thinking. As we can see, the first four types of thinking - mythological, totemic, formal, logical - form a basis for the emergence of systemic thinking that can be also differentiated based on the degree of complexity.

We will emphasize once again an important observation: when a person begins to think systemically about any (including ecological) subject, there is a deletion of the borders separating ecological, economic and social areas; they become connected. And even if the attentional focus remains on the environment, solving practical tasks is impossible without understanding processes happening in the neighboring systems.

Therefore, ecological education (ecological consciousness, education, etc.), from our point of view, assumes only an initial entrance to an environmental problem, which will change through profound consideration, and the view of it will be transformed.

7. Each phenomenon (a situation, an event, or a subject) can be considered from the angle of different types of thinking. This will only enrich a perspective, and will add knowledge of it.

It is noteworthy that the answer to the same question will be totally different from the perspectives of different types of thinking.

\section{For example: Why do I switch off the water when I brush my teeth?}

Mythological: They say that resources are limited in our country. There was a TV program on this subject.. I think it is right to do so if reserves of fresh water are small.

Totemic: Recently I watched an interview with my favorite BB, and she switches off the water. I consider that BB is an outstanding actress and a defender of animal rights; she helps homeless dogs; she can't be mistaken. I will switch off the water too. Another option is: "why do I switch off the water? Mother has also taught me to do so, and she won't advise anything bad... “

Formal: In our community everybody switches off the water, because we all care for the resources of our planet.

Logical: Switching the water off when brushing teeth is correct. The more often I do it, the smaller the water bill to be paid. Another option is: "I read a lot about the ecological footprint, therefore I consciously reduce the load on the environment."

Associative: In the museum of water, it was told that water arrives from water treatment facilities that work using renewable and non-renewable resources. 
When I switch off the water, I specifically reduce the workload of these treatment facilities... The point of this action is that I help to preserve resources.

Figurative: The essence of this action consists in respecting the Planet as a single organism.

Abstract: I do it as I personally work for water-purifying facilities (or I am the author of energy-saving programs).

As we can see, the scale and depth of answers to this apparently simple question can vary rather significantly.

\section{Conclusions}

In the Club of Rome's report for 2017 the verdict given was that "The old World is doomed. The new World is inevitable" (von Weizsaecker \& Wijkman, 2018). In order to implement the ideas of "new Education", it is necessary to form thinking as the ability to perceive, organize, coordinate and reunite separate fragments, and to reach an original understanding of fundamental reality. And this means that until a person does not reconstruct thought, changes relating to environmental problems will not happen.

In this article we have described types of thinking and their contribution to the ecological thinking. Central, however, is the question of ways of educating thinking on such a level.

The initial stage can consist in the identification of specific features of thinking in various social and psychological groups of the population - preschool children, school students, city people, villagers, intellectuals, people without education, etc. - and the use of these features with the goal of protecting the environment.

This is an attempt to carry on the conversation about environmental problems in language that will be, most of all, clear to this group of the population. Forms of conducting a conversation (ecological excursions, popular lectures, performances of public figures in media, etc.) have to be carried out taking into account features of the type of thinking of the groups for which they are intended. Formation of types of thinking will contribute to the development of ecological thinking.

The problem of the development of thinking can and must become a priority in ecological education.

\section{References}

Balgopal, M., \& Wallace, A. (2009). Decisions and dilemmas: using writing to learn activities to increase ecological literacy. The Journal of Environmental Education, 40(3), 13-26.

Baum, P. (2013). Thought forms - The structure, power, and limitations of thought (Vol. 1). Aesir Publishing.

Blenkinsop, S., Piersol, L., \& Sitka-Sage, M. (2018). Boys being boys: Eco-Double consciousness, splash violence, and environmental education. In C. Russell, A. Gough, \& H. Whitehouse (Eds.), Gender and environmental education 2 [Special issue]. The Journal of Environmental Education, 49(4), 350-356. 
Campbell, J. (1972). Myths to live by. New York: Viking Press.

Campigotto, R., \& Barrett, S. E. (2017). Creating space for teacher activism in environmental education: Pre-service teachers' experiences. Canadian Journal of Environmental Education, 22, 42-58.

Capra, F. (1996). The web of life: a new scientific understanding of living systems. New York: Anchor Books. Dilts, R. (2001). Strategies of genius (in 3 vols). Meta Pubns.

Frazer, J. G. (2015). The golden bough (in 12 vols). CreateSpace Independent Publishing Platform.

Gharajedaghi, J. (2011). Systems thinking: Managing chaos and complexity. Gardners Books.

Gifford, R., \& Sussman, R. (2012). Environmental attitudes. In S. D. Clayton (Ed.), The Oxford handbook of environmental and conservation psychology (pp. 65-80). Oxford, UK: Oxford University Press.

Hintz, C. J., \& Lackey, B. K. (2017). Assessing community needs for expanding environmental education programming. Applied Environmental Education and Communication, 16, $287-297$.

Lapitov, I. V. (2009). Etnicheskaya psikhologiya [Ethnic psychology]. Khabarovsk: Far Eastern Federal University. (in Russian)

Leontiev, D. A. (2008). Teoriya lichnosti A. Lazurskogo [Lazursky's theory of personality]. Metodologiya i Istoriya Psikhologii [Methodology and History of Psychology], 3(4), 7-20. (in Russian)

Lévi-Strauss, C. (1999). Pervobytnoe myshlenie [Primitive thinking]. Moscow: Terra. (in Russian)

Meshcheryakov, B., \& Zinchenko, V. (Eds.). (2003). Bol'shoy psikhologicheskiy slovar' [The great psychological dictionary]. Saint Petersburg/Moscow: Praim-Evroznak/Olma-Press. (in Russian)

Norizan, E., Hashimah, Y., Nooraida, Y., Mahamad, H., \& Mardiana, I. (2018). Enhancing students' ecological thinking to improve understanding of environmental risk. Retrieved from https://www.researchgate.net/publication/282948086_Enhancing_Students'_Ecological_Think ing_to_Improve_Understanding_of_Environmental_Risk

O'Connor, J., \& McDermott, I. (2012). The art of system thinking. London: Thorsons.

Pinker, S. (2008). The stuff of thought: Language as a window into human nature. Penguin Books.

Pogodin, I. A. (2013). A dialogical phenomenological model of thinking: resources of primary experience Psychology. Journal of the Higher School of Economics, 10(3), 109-118. (in Russian)

Resnick, M. (2003). Thinking like a tree (and other forms of ecological thinking). International Journal of Computers for Mathematical Learning, 8(1), 43-62.

Smolova, L. V. (2019). Systematic thinking as a factor in implementing sustainable development. In W. Leal Filho \& A. Consorte McCrea (Eds.), Sustainability and the humanities (pp. 443-454). Cham, Switzerland: Springer.

Stevenson, R. B., Brody, M., Dillon, J., \& Wals, A. E. J. (2014). International handbook of research on environmental education. Washington, DC: The American Educational Research Association (AERA).

Von Weizsaecker, E., \& Wijkman, A. (2018). Come on! Capitalism, short-termism, population and the destruction of the planet. New York: Springer.

Woolpert, S. (July 24, 2004). "Ecological thinking”: A bridge between scientific and religious perspectives on environmental protection. Paper delivered at The Second International Conference on New Directions in the Humanities at the Monash University Centre in Prato, Italy.

Zook, C., \& Allen, J. (2016). The founder's mentality: How to overcome the predictable crises of growth. Boston, MA: Harvard Business Review Press.

Lidia V. Smolova - associate professor, Department of Psychological Counseling, St. Petersburg State Institute of Psychology and Social Work, Ph.D.

Research area: psychological counselling, logotheraphy, environmental psychology, residential environment, ecological consciousness.

E-mail: Lidia_smolova@mail.ru 


\title{
Виды мышления и их вклад в экологическое образование
}

\author{
Л.В. Смолова ${ }^{\mathrm{a}}$ \\ ${ }^{a}$ Санкт-Петербургский государственный институт психологии и сочиальной работы, 199178, \\ Россия, Санкт-Петербург, 12 линия В.О., дом 13A
}

\section{Резюме}

В статье раскрываются виды мышления с позиций синтеза антропологии, философии и психологии: мифологическое, тотемное, формальное, логическое, ассоциативное, образное, абстрактное. Подчеркиваются ценность и уникальность каждого вида мышления как способа познания мира. Описываются преемственность, усложнение, эволюционность видов мышления, которые находятся между собой в определенных иерархических отношениях. Указывается, что все виды мышления присутствуют у каждого человека в потенциале. Констатируется, что каждое явление (ситуацию, событие, предмет) можно рассмотреть ракурсом разных видов мышления: это только обогатит взгляд и дополнит знания о нем. Описывается возможный вклад каждого вида мышления в экологическое образование и изменение экологических установок. Подчеркивается, что виды мышления являются сознательным или не осознанным инструментом, которые возможно и необходимо применять с целью прояснения тех ориентиров и пусковых механизмов, которые лежат в основании экологического поведения, а также помощи человеку любого возраста научиться мыслить интегрально, системно, осмысленно. Осознавание видов мышления поможет людям в поиске их личных смыслов дружественного поведения к окружающей среде и изменении экологических установок.

Ключевые слова: виды мышления, системное мышление, экологические установки, глобальное мышление, экологическое мышление, экологическое образование, устойчивое развитие, Римский клуб.

Смолова Лидия Владимировна - доцент, кафедра консультативной психологии и психологии здоровья, Санкт-Петербургский государственный институт психологии и социальной работы, кандидат психологических наук, доцент.

Сфера научных интересов: психологическое консультирование, логотерапия, психология смысла, психология взаимодействия с окружающей средой, жилая среда, экологическое сознание.

Контакты: Lidia_smolova@mail.ru 